\title{
PRESCHOOL EDUCATION VERSUS CURRICULAR REFORM
}

\section{Eva ŠMELOVÁ}

\begin{abstract}
The curricular reform, its strategies and implementation requires a systematic and thorough reflection that should monitor the impact and effect on education at all levels. The curriculum is being reviewed in order to react to and eliminate any problems with an objective to increase the quality of Czech education.

The aim of the article is to inform readers about the current issues of the ongoing curricular reform in the Czech Republic with an emphasis on preschool education in the context of a research study performed within a Czech Science Foundation scheme at the Faculty of Education, Palacký University, Olomouc focusing on children's readiness for starting compulsory school attendance. The research was carried out from 2009 to 2012 and provided data that identify problem areas in preschool education.
\end{abstract}

Key words: curriculum, reform, curriculum review, kindergarten, preschooler, school maturity, research, compulsory school attendance

\section{PŘEDŠKOLNÍ VZDĚLÁVÁNÍ VERSUS KURIKULÁRNÍ REFORMA}

Resumé: Kurikulární reforma, její strategie a uvádění do praxe vyžaduje systematickou a důslednou reflexi, která by měla sledovat její dopad a efekty ve vzdělávání na všech úrovních škol. Revize kurikula by měla reagovat a eliminovat zjištěné problémy, s cílem zvyšovat kvalitu českého školství.

Cílem příspěvku je seznámit čtenáře s aktuálními otázkami probíhající kurikulární reformy v České republice se zaměřením na oblast předškolního vzdělávání v kontextu výzkumu, který byl realizovaný v rámci GAČR na Pedagogické fakultě UP v Olomouci a zabýval se na prripraveností dětí k zahájení povinné školní docházky. Výzkum probíhal v letech 2009 - 2012 a poskytl mimo jiné data, která avizují problematické oblasti v předškolním vzdělávání.

Klićcová slova: kurikulum, reforma, revize kurikula, mateřská škola, dítě předškolního věku, školní zralost, výzkum, povinná školní docházka.

\section{1 Úvod}

Po roce 1989 dochází v naší zemi k zásadním politickým, ale i společenským změnám, které se př́mo dotýkají vzdělávací politiky státu, a to v evropském i globálním kontextu. Za významný mezník v tomto procesu lze považovat vydání Národního programu rozvoje vzdělávání v České republice (Bílá kniha, 2001). Dokument vymezil východiska proměn českého školství. Nastavenou strategii lze považovat za soubor podnětů pro práci škol v souladu s jejich podmínkami a možnostmi. Jedná se o otevřený dokument, který musí procházet $\mathrm{v}$ určitých časových intervalech

nezbytným kritickým posouzením, s ohledem na potřeby společnosti.

\section{Předškolní vzdělávání v kontextu naplňování cílů vzdělávací politiky}

Jedním z hlavních cílů vzdělávací politiky je posílení rozvoje předškolního vzdělávání. V současné době je plnění tohoto cíle zejména $\mathrm{v}$ rukou místních orgánů měst a obcí, které ne vždy vytvářejí s ohledem na vlastní ekonomickou situaci či zájmy obce potřebné podmínky.

K dalším prioritám patř́ zvyšování kvality vzdělávání prostřednictvím vzdělávacích programů, které reflektují potřeby moderní, demokratické společnosti.

Z analýzy naplňování cílů Bíle knihy (2001), která byla zveřejněna $\mathrm{v}$ roce 2009 , vyplývá řada problémů, které se přímo dotýkají práce škol a mohou vést ke snížení kvality vzdělávací práce a jejich výsledků. Například avizovaný Státní program nebyl zpracovaný a jeho absence, jako zastřešujícího dokumentu, se odráží v nejednotně pojímané vizi dodnes.

Pokud vezmeme v úvahu, že vize představuje základní sjednocující východisko reformy jako procesu, je zřejmé, že již na samém začátku došlo k zásadnímu pochybení. Uvedená skutečnost se ukazuje doposud, a to v nepochopení a v nedostatečném přijetí současného kurikula.

Každá odborná publikace managementu seznamuje se základními kroky při zavádění 
změny, kde musí být jasná vize a připravený terén pro její implementaci. Ta potom může následovat, ale ne chaoticky. Jedná se o proces, vyžadující systematické monitorování s cílem eliminovat a pružně reagovat na možné problémy.

Ani $\mathrm{v}$ této oblasti nebylo postupováno promyšleně. Proces monitoringu lze považovat za nedostatečný. Č́stečný pohled na implementaci nového kurikula přinášela sice Česká školní inspekce, Rychlá šetření NÚV (2002 - 2008) a dílčí výzkumy. Komplexní pohled ale postrádáme.

První verze Rámcového vzdělávacího programu pro předškolní vzdělávání (dále RVP PV), určená jako pokusná, byla vydaná $\mathrm{v}$ roce 2001 , v roce 2005 byl RVP PV schválený a od 1. 9. 2007 se stává závazným kurikulárním dokumentem.

Přestože od roku 2001 uplynulo dvanáct let, stále se setkáváme s nepochopením koncepce kurikula, jeho terminologie, pojetím cílů apod. (Šmelová 2004, 2008, 2009). Jak ukazuje praxe, RVP PV na pedagoga a jeho odbornost klade vyšší nároky. Tato oblast se př́mo dotýká profesního a dalšího vzdělávání předškolních pedagogů.

Byla tedy skutečně na počátku př́prava učiteli̊ pro práci s novým kurikulem systematická a na odpovídajicí odborné úrovni?

Zde je nutné připomenout počátky, kdy do vzdělávání vstupovala řada lektorů a vzdělávacích institucí mnohdy bez potřebné znalosti problematiky.

S podobnými problémy se setkáváme i např. na základních školách, jak uvádí např. Fasnerová, Petrová (2008).

Uvedené skutečnosti se odrážejí v mateřských školách nejenom na úrovni školní, ale následně i $\mathrm{v}$ projektování na úrovni tř́́dy, kde $\mathrm{k}$ zásadním problémům patří nezvládnutí plánovat vlastní práci s ohledem na potřebu a možnosti jednotlivých dětí.

Zde si můžeme položit další otázky: Do jaké miry se tyto skutečnosti odrážejí do kvality práce předškolniho pedagoga? Existuje souvislost mezi uvedenými problémy a vysokými počty odkladú školni docházky?

\section{Co ukazuje výzkum}

Pracovníci Katedry primární a preprimární pedagogiky (Šmelová), Katedry psychologie a patopsychologie (Petrová, Plevová, Pugnerová, Křeménková, Dařilek) a Ústavu speciálně pedagogických studií (Souralová) na PdF UP v Olomouci uskutečnili v letech 2009 - 2012 výzkum, v němž se zaměřili na připravenost dětí k zahájení povinné školní docházky české populace $\mathrm{v}$ kontextu předškolního kurikula. Současně provedli výzkumná šetření se stejnou metodologií ve spolupráci se zahraničními partnery ve Slovinsku, na Slovensku a v Polsku.

Výzkumný soubor ČR zahrnoval 931 dětí. $\mathrm{Z}$ hlediska pohlaví bylo ve sledovaném souboru celkem 405 dívek (průměrný věk (73,31 měsíce), 49 dívek s odkladem školní docházky (průměrný věk 76,63 měsíce), chlapců bylo 376 (průměrný věk 73,84 měsíce), chlapců s odkladem školní docházky bylo 101 (průměrný věk 77,67 měsíce).

Byla použita jednotná testová baterie, která obsahovala sadu deseti testových úkolů.

Pro ilustraci prezentujeme $\mathrm{v}$ príspěvku výsledky orientačního testu školní zralosti (Jirásek, 1982), který patř́ již po mnoho let $\mathrm{k}$ nejefektivnějším orientačním testům pro danou oblast. Pro naše potřeby nám predikuje slabá místa a rezervy v současném předškolním vzdělávání, které se vztahuje k přímé pedagogické práci učitele mateřské školy.

Test obsahuje tři úkoly:

A. Kresbu mužské postavy (JAZ)

B. Napodobení psacího písma (JBZ)

C. Obkreslení skupiny bodů (JCZ)

Hodnocení je prováděno na pěti bodové klasifikační stupnici.

Ad 1 Děti bez odkladu školni docházky
\begin{tabular}{|l|c|c|}
\hline & chlapci (376) & děvčata (405) \\
\hline$J A Z$ & 2,83 & 2,44 \\
\hline$J B Z$ & 2,53 & 2,27 \\
\hline$J C Z$ & 2,28 & 2,14 \\
\hline
\end{tabular}

Výsledky ukazují, že ve všech třech úkolech dosahují děvčata ve srovnání s chlapci lepších výsledků. Hodnocení ve všech oblastech u obou skupin se pohybuje v průměru nebo na jeho dolní hranici.

Ad 2 Děti ve vztahu ke vzdělání rodičù
\begin{tabular}{|l|c|c|c|}
\hline & základni & středoškolské & vysokoškolské \\
\hline$J A Z$ & 2,86 & 2,58 & 2,51 \\
\hline$J B Z$ & 2,69 & 2,31 & 2,3 \\
\hline$J C Z$ & 2,35 & 2,19 & 2,13 \\
\hline
\end{tabular}

Výsledky ukazují, že ve všech třech úkolech dosahují nejlepších výsledků děti rodičů $\mathrm{s}$ vysokoškolským vzděláním. $\mathrm{V}$ této souvislosti 
můžeme konstatovat, že významný vliv vzdělání rodičů se nám potvrdil u většiny testových úkolů.

Ad 3 Děti sodkladem a bez odkladu školní docházky

\begin{tabular}{|c|c|c|}
\hline & s odkladem & bez odkladu \\
\hline$J A Z$ & 3,03 & 2,63 \\
\hline$J B Z$ & 2,96 & 2,4 \\
\hline$J C Z$ & 2,37 & 2,21 \\
\hline
\end{tabular}

Výsledky potvrzují, že děti s odkladem školní docházky, i po jeho absolvování, ve všech oblastech dosahují slabší výsledky ve srovnání s dětmi bez odkladu školní docházky. Upozornit ale musíme na to, že u dětí s odkladem došlo vždy k výraznému zlepšení.

Pokud bychom si ukázali i další ve výzkumu sledované oblasti, setkali bychom se převážně s velmi podobnými výsledky. Uvedená skutečnost nás upozorňuje, že děti se ve sledovaných oblastech pohybují v průměru, mnohdy spíše na jeho dolní hranici. Jako významné se ukazují výsledky ve prospěch dětí rodičů $\mathrm{s}$ vyšším vzděláním. Za zcela zásadní považujeme výsledky, které hovoří ve prospěch odkladů školní docházky. Tuto skutečnost zcela jistě ovlivňuje vyšší úroveň zralosti CNS, děti již jsou soustředěnější, dosahují lepší úrovně celkové koordinace pohybu apod.

Celý výzkum je podrobně popsaný v publikaci Šmelová, Petrová, Souralová a kol. (2012), kde se autorský kolektiv věnuje zejména české populaci dětí. Anglická verze publikace se zaměruje i na komparaci populace dětí z Česka, Slovinska, Slovenska a Polska.

\section{Výsledky výzkumu jako možné východisko revize kurikula}

Zásadní problém v práci mateřských škol spatřujeme $\mathrm{v}$ nedostatečné dovednosti či nedocenění projektování v souladu s vývojovou úrovní dítěte, s ohledem na jeho individualitu, zájmy a potřeby.

RVP PV učitelům pouze říká, čeho má dítě $\mathrm{v}$ rámci svých možností dosáhnout před zahájením povinné školní docházky, což ale vyžaduje kvalitní orientaci pedagoga ve vývojových řadách dítěte předškolního věku a zvládnutí pedagogické diagnostiky.

Jedná se o zásadní dovednosti, které se odrážejí $\mathrm{v}$ prrípravě podnětného prostředí, ve výběru vhodných her a vzdělávacích aktivit s ohledem na individualitu dítěte. To vše potom umožní učiteli kvalifikovaný př́istup $\mathrm{k}$ dítěti a $\mathrm{k}$ realizaci edukačního procesu tzv. „sitého na míru".

V této souvislosti stojí za zmínku připomenutí Vygotského ,zóny nejbližšiho vývoje“, kterou definuje jako vzdálenost mezi dvěma rovinami, a to úrovní současného vývoje, kde je dítě schopno řešit problémy samostatně a úrovní, kde dítě potřebuje $k$ řešení pomoc druhého. Stávající úroveň představuje míru minulého vývoje. Zóna nejbližšího vývoje představuje potenciál procesů, které dozrávají. (Bertrand, 1998)

Dnešní předškolní vzdělávání zdůrazňuje odklon od transmisivních př́stupů. Východiska pro současné pojetí nalézáme tedy např. v kognitivně psychologických teoriích (Piaget) či sociokognitivních teoriích (Vygotskij).

Do určité míry můžeme do př́mé souvislosti dávat učitelovo pojetí kurikula a již zmiňované odklady školní docházky.

Zahájení povinné školní docházky představuje významný a náročný mezník v životě dítěte, na nějž jsou kladeny nové nároky. Dítě současně vstupuje do nových rolí, což je spojeno $s$ adaptačními problémy, které $u$ většiny dětí po krátké době ustupují. Setkáváme se ale i se skupinou dětí, jejichž schopnost nepřizpůsobení se školním podmínkám přetrvává, což sebou nese řadu „,nabalujicich“ “ se problémů, které většinou vyústí ve školní neúspěšnost. Východiska zde sice jsou, dítě se může např. vrátit zpět do MŠ, ale toto řešení může mít nepříznivý dopad, který se odrazí v negativním vztahu ke škole, učení, ale i v samotném sebepojetí jedince. Tlak rodiny na lepší výkon dítěte může vyústit do různých psychických problémů (ranní zvracení, bolesti hlavy, poruchy spánku).

Zralost CNS dítěte ve vztahu k prripravenosti pro zahájení povinné školní docházky považujeme za zásadní, ale vliv prostředí sehrává taktéž významnou roli.

Mateřská škola má řadu možností pomoci, a to nejenom přímým pedagogickým působením, ale i prostřednictvím spolupráce s rodiči, odborníky atd.

Pomoci vybavit dítě pro vstup do základní školy nezbytnými elementárními kompetencemi by mělo i kvalitní kurikulum, které udává směr a je oporou pro působení učitele. Domníváme se, že by pomohla rekonstrukce stávajícího kurikula, a to $\mathrm{z}$ hlediska výstupů do dvou věkových kategorií $(3-5,5-6)$.

Nově nastavené výstupy by ukázaly učitelům včas na problematické oblasti a pomohly by jim 
systematicky s dítětem pracovat celý rok před zahájením povinné školní docházky.

Opomíjena by neměla být návaznost a užší propojenost preprimárního a primárního vzdělávání. Dítě do základní školy nevstupuje jako „nepopsaná deska“, jak někdy slyší učitelé mateřských škol od svých kolegů ze školy základní, ale je již vybavené řadou dovedností, poznatků apod., na něž by měla škola navazovat.

\section{Závěr}

I když si předškolní vzdělávání neklade za cíl př́pravu dítěte na vstup do školy, musíme si uvědomit, že dítě připravujeme pro život a součást jeho života je i vstup do základní školy jako navazující vzdělávací etapy na předškolní vzdělávání, které je sice nepovinné, ale velmi významné pro další vývoj jedince.

\section{Literatura}

[1] BERTRAND, Y. Soudobé teorie vzdělávání. Praha: Portál, 1998. ISBN 80-7178-216-5.

[2] FASNEROVÁ, M, PETROVÁ, J. Zkušenosti S novou školskou reformou na základní škole. In Škola $v$ dialogu kultury, pedagogiky a společnosti. Sborník z pedagogické konference. Liberec: TU, 2008. ISBN 978-80-7372-414-6. [3] JIRÁSEK, J. Orientační test školnípríručka. Bratislava: Psychodiagnostika, 1992. [4] LANGMEIER, J., KREJČÍŘOVÁ, D. Vývojová psychologie. Praha: Grada, 2006. ISBN 80-247-1284-9.

[5] ŠMELOVÁ, E. Dítě v kontextu současného předškolního vzdělávání. In Pedagogický výzkum jako proměna současné školy. Sborník př́spěvků 16. konference $\check{C} A P V$. [CD-ROM], Hradec Králové: PdF, 2008. ISBN 978-80-7041-958-8.

[6] ŠMELOVÁ, E. Práce s výukovými cíli při tvorbě třídního vzdělávacího programu v MŠ. In Profese učitele a současná společnost. Sbornik príspěvků z 12. konference ČAPV. [CD-ROM], Ústí nad Labem: UJEP, 2004. ISBN 80-7044571-8.
[7] ŠMELOVÁ, E. Terminologie RVP PV jako pedagogický problém. In Hornáčková, V. Dítě předškolního věku a jeho paidagogos: sborník prŕspěvků z mezinárodní vědecké konference [CD-ROM], Hradec Králové: PdF, 2009. ISBN 978-80-7041-647-1.

[8] ŠMELOVÁ, E., PETROVÁ, A., SOURALOVÁ, E. a kol. Pripravenost dètí $k$ zahájeni povinné školni docházky v kontextu současného kurikula. Olomouc: UP, 2012. ISBN 978-80-244-3345-5.

[9] ŠMELOVÁ, E., PETROVÁ, A., SOURALOVÁ, E. a kol. Pre-school education in the context of curriculum. Olomouc: UP, 2012. ISBN 978-80-244-3370-7.

[10] ŠMELOVÁ, E., PETROVÁ, A., SOURALOVÁ, E. a kol. Připravenost dětí $k$ zahájeni povinné školni docházky v kontextu současného kurikula. Olomouc: UP, 2012. ISBN 978-80-244-3345-5.

\section{Dokumenty}

[1]Analýza naplnění cílů Národního programu rozvoje vzdělávání v České republice (Bílé knihy) $v$ oblasti predškolního, základniho a středního vzdéláváni [online]. 2009 [citováno: 2013-06-6]. Dostupný z www. msmt.cz.

[2] Národni program rozvoje vzděláváni v $\check{C} R$. Praha: Tauris, 2001. ISBN 80-211-0372-8.

doc. PhDr. Eva Šmelová, Ph.D.

Katedra primární a preprimární pedagogiky

Pedagogická fakulta UP

Žižkovo nám. č. 5

77140 Olomouc, $\check{C} R$

Tel: +420 585635105

E-mail: eva.smelova@upol.cz

Www pracoviště: www.kpv.upol.cz 